Article

\title{
Co-Operation among Irish Beef Farmers: Current Perspectives and Future Prospects in the Context of New Producer Organisation (PO) Legislation
}

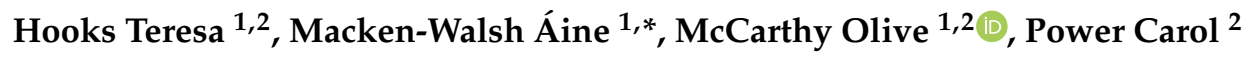 \\ and Henchion Maeve ${ }^{3}$ (D) \\ 1 Rural Economy and Development Programme, Mellows Campus, Teagasc, Athenry, \\ H65R718 Galway, Ireland; teresa.hooks@ucd.ie (H.T.); o.mccarthy@ucc.ie (M.O.) \\ 2 Centre for Co-Operative Studies and Department of Food Business \& Development, O’Rahilly Building, \\ University College, T12 CY82 Cork, Ireland; CPower@ucc.ie \\ 3 Rural Economy and Development Programme, Teagasc, Ashtown, D15 KN3K Dublin, Ireland; \\ Maeve.henchion@teagasc.ie \\ * Correspondence: aine.mackenwalsh@teagasc.ie; Tel.: +353-91-845-200
}

Received: 19 September 2018; Accepted: 3 November 2018; Published: 7 November 2018

check for updates

\begin{abstract}
Irish beef farms have experienced poor viability longitudinally, with industry and policy actors citing 'crisis' levels in 2013. A crucial differentiator between the beef sector and the dairy sector, which has higher farm incomes, is well-developed infrastructure of farmer-owned dairy processing and marketing co-operatives. To address the lack of representative farmer organisations and power imbalances in the beef supply chain, in 2016 the Department of Agriculture Food and the Marine (DAFM) legislated for the establishment of beef Producer Organisations (POs), facilitating beef producers to collectively strengthen their market positioning. While PO legislation is a significant development in potentially enabling supply chain integration of farmers, how the legislation is operationalised by Irish beef industry stakeholders will ultimately shape the nature and breadth of engagement with the PO model and, consequently, the impact of the legislation. In a context where there is little or no prior experience of such organisations in the beef sector, this paper presents an analysis of current stakeholder views in relation to the establishment of POs. Research involved a desk based review of the submissions made during the consultation period for the beef PO legislation and interviews with key informants in the Irish beef industry. We analysed Irish stakeholders' views through the lens of lessons learned from the existing literature on how POs operate internationally. Results indicate some stakeholders' perceptions of the need for a nationally coordinated approach in the establishment of an Association of POs, which concurs with the literature. However, stakeholders have not emphasised the benefits of Interbranch Organisations (IBOs), which involve vertical collaboration with other chain actors such as processors and retailers, an approach that has proven successful internationally. Nor have Irish stakeholders identified the potential of differentiating or premiumising beef products, which, according to international evidence, is necessary for improving profitability and farm-level incomes. Stakeholders identified the main threats to the future success of POs in Ireland as members' lack of commitment and processors' lack of willingness to engage with POs.
\end{abstract}

Keywords: Ireland; beef farms; producer organisations; product differentiation; co-operative; values-based supply chain 


\section{Introduction}

The Irish beef sector is Irelands largest agricultural sector with over 100,000 beef farms involved and in 2016 had a value of $€ 6.92$ billion [1]. It is a highly export oriented sector, exporting $90 \%$ of total output [1]. Despite the size and overall value of the sector, there is little or no profitability at farm-level [2-4]. For example, only $26.3 \%$ of beef farms were categorised as economically viable in 2016 [5]. Due to poor market returns, the beef sector is highly dependent on EU payments and off farm employment [5]. In comparison, the Irish dairy sector is the most profitable sector. While there are multiple explanatory factors explaining differences between the dairy and beef sectors, one of the significant differences relates to the institutional characteristics of their respective supply chains. Since the late 19th century, farmer owned co-operatives have formed an integral part of the Irish dairy sector and are considered vital to the stability and growth of the sector [6]. However, farmers remain largely unorganised in the beef sector with the notable exception of the co-operative 'mart' centres, primary functions of which are to provide a transparent method of selling livestock and securing payment [7]. The marts, by contrast to dairy sector co-operatives, undertake no processing activities and are not vertically integrated to the supply chain. Viability is defined as providing the average agricultural wage for family labour in addition to providing a 5\% return on non-land assets [8].

The poor economic viability of beef farmers is often attributed to asymmetries of power within the beef supply chain, which have been described as favouring processors and retailers [9]. The Producer Organisation (PO) model has been offered as a vehicle to "rebalance the supply chain by strengthening the hand of producers" [10]. The PO is simply defined as "a legally constituted group of farmers" [11] and is intended to support farmers to integrate to the supply chain by creating scale and collective bargaining power [12,13].

Two events in 2013 combined to provide the catalyst for the introduction of beef PO legislation in Ireland. Firstly, at the EU level, the Common Market Organisation (CMO) EU Regulation 1308/2013 extended legal recognition of POs to all production sectors at the discretion of individual member states. Secondly, there was official recognition of a 'beef crisis' in Ireland because of low prices paid to beef farmers. The 'crisis' was attributed to a number of factors including production driven systems; export blockades; power imbalances within the chain; poor flow of information across the chain; the horsemeat scandal; and processors' cattle specifications (weight targets and carcass conformation). Lack of transparency and communication between different actors in the chain generated mistrust and suspicions of profiteering further down the chain ([9], p. 21).) A 'Beef Forum 'was initiated by the DAFM in April 2014 to respond to these issues and involved essentially a series of roundtable talks involving industry stakeholders to identify potential solutions. The Dowling Report was the main outcome of the forum, which recommended that the role of POs be examined as a strategy to deal with power imbalances in the supply chain [14]. The implementation of beef PO legislation allows beef farmers to negotiate collectively with meat factories without breaching competition rules (under certain conditions) $[14,15]$. While PO legislation can is a significant development in potentially enabling supply chain integration of farmers, how the legislation is operationalised by Irish beef industry stakeholders will ultimately shape the nature and breadth of engagement with the PO model and, consequently, the impact of the legislation. POs were first introduced in the EU in 1972 [16] and organised mostly in the fruit and vegetable sector. PO legislation was extended to the dairy sector in 2011 and to all sectors in 2013.

Following an overview of the Irish beef sector and a review of state of the art in the formation and operation of POs, this paper presents a straightforward analysis of current perspectives and future prospects for the establishment of beef POs in Ireland. The analysis is based on qualitative interviews undertaken with key informants in the Irish beef industry in 2016 and 2017 and the full collection of stakeholder submissions made to the DAFM during the 2014 beef PO legislation public consultation process. Following the topics used by DAFM in eliciting stakeholders' views in a public consultation process, we focus on: stakeholders' views on how POs should be formed and operated: the size (membership/throughput) that POs ought to be; the structures and governance appropriate for POs; 
the main functions (marketing, on-farm efficiencies, climate change mitigation inter alia) POs ought to assume; and the nature of POs' roles in contractual negotiations. We discuss Irish stakeholders' views through the lens of lessons learned from the existing literature on how POs operate internationally. After a brief description of the Irish beef sector in section two, we review the international literature on POs and associated cooperative structures in section three. We then present our methods, findings and discussion in sections four, five and six.

\section{Context}

\subsection{The Irish Beef Sector}

Over 500,000 tonnes of beef are produced annually in Ireland, with over 90\% exported on an annual basis. Ireland's beef self-sufficiency rate is estimated at $650 \%$ and therefore the sector is highly reliant on exports [1]. The Irish beef supply chain is characterised by a diverse range of actors spanning input-suppliers, farmers, multiple animal sales outlets, processing, distribution and retailing outlets. The Irish beef supply chain is characterised by heterogeneity of beef production systems at farm-level (for example cattle rearing, cattle finishing), types of beef animals (ranging from suckler cows, calves, heifers, young cattle, bulls and steers) and breed varieties [17-19].

In Ireland there are 32 major export-approved privately owned slaughtering facilities and 195 low-volume slaughterhouses [20]. Four main processors, however, account for the largest proportion of Irish beef $(65 \%$ in 2015) [9]. In the context of such consolidation in the Irish meat processing sector there have been unsubstantiated claims of 'price fixing' and 'cartels' [21,22]. The value of Irish beef output, for the purposes of national policies such as Food Wise 2025, is measured on the basis of prices paid to farmers. Thus, considering policy targets to increase the value of Irish beef output by $20 \%$ by 2025 , prices paid to farmers is a chief concern. While efforts through Ireland's food marketing board (Bord Bia) can attempt to improve the marketability of Irish beef in international markets, the ultimate determinant of prices paid for $65 \%$ of Irish beef output is at the discretion of four private companies. In this context, the importance of balancing power in the supply chain between processors and farmers in particular becomes apparent.

While the vast majority of processing in the dairy sector is undertaken by farmer-owned co-operatives, no co-operatives have processing functions in the beef sector. Mart cooperatives, however, are common in the beef sector and are present nationwide. There is, however, a well-established network of marts for a half a century in Ireland, having replaced livestock fairs, which had been in place for seven centuries before [23]. The Irish Co-operative Organisation Society (ICOS) reports that there are currently over 60 co-operative marts in Ireland, which have the primary function of providing a 'transparent method of selling and guaranteeing payment for livestock' [7]. In addition to mart co-operatives, there are over 40 breed societies that operate as co-operatives [7]. Research examining mart co-operatives in Ireland found that most are loss making and require diversification [23]. Non-mart activities, such as real estate, were found to account for $90-100 \%$ of marts engaged in diversified activities, including the four largest Irish mart co-operatives ([23], p. 13). Differentiating between horizontal and vertical integration, analysis of interviews conducted with senior executives of marts found that they preferred horizontal integration by merger rather than vertical cooperation with retailers and processors. However, interviewees foresaw that board members of individual marts were unlikely to agree to horizontal merger [23]. The authors' analysis found that vertical integration, by undertaking downstream activities such as processing, was not favoured by marts, though no specific reason for this was identified. The most desirable strategy among senior executives was diversification of marts into other areas (real estate, retailing agricultural supplies), which has accelerated over the past two decades. Consistent with these 2002 predictions, no cooperative mart organisation undertakes processing activities today. In this context, the differences between current mart organisations (which have diversified into non-supply chain areas) and the activities of POs (which integrate to have a greater presence in the supply chain) are apparent. However, if 
mart organisations were to diversify to undertake vertical cooperation activities in the supply chain, they would be comparable to POs. A highly favourable feature of marts as cooperatives is that they already have strong farmer memberships, which makes them suitable organisations for deepening their involvement in the supply chain and registering and functioning as POs.

\subsection{Producer Organisations}

Power imbalances in the beef supply chain, identified as largely responsible for the loss-making status of Irish beef farms, go largely unaddressed by current institutional conditions in Ireland $[9,24]$. It is in this context that POs were proposed as an organisational method to disrupt and rebalance negotiating power between producers and processors. POs are legal entities, governed by EU regulation 1308/2013 and facilitate the types of horizontal and vertical integration strategies analysed by other authors in the context of the Irish mart cooperative system [23]. POs are not confined to agriculture and also operate in the fisheries sector, where there are currently over 200 POs operating EU-wide, governed separately by EU regulation 1419/2013. However, policy recognition and support of POs across the various agriculture and aquaculture sectors is driven by the same goals, as described by the European Commission,

"Producer organisations (whether or not organised in the form of co-operatives) and their associations are important players which contribute to strengthening the position of farmers and growers in the food supply chain versus other downstream actors by carrying out a wide array of activities on behalf of their members. By working more closely, producers will be able to achieve economics of scales and synergies to process and market the products of their members." [25]

While there are over 22,000 agricultural co-operatives operating across the EU [26], the presence of formally recognised POs tends to vary across countries and sectors [13]. Approximately half of the value of all marketable vegetables and fruit produced in the EU is marketed through legally recognised POs ([27], p. 6) and in Ireland 20\% of fruit and vegetables are marketed through recognised POs [28]. POs in the EU operate across a range of sectors including: cereals, sugar, pork, sheep meat, fruits and vegetables, olive oil, dairy, wine and beef, although the majority have tended to operate in the fruit and vegetable sector in the most part because fruit and vegetable POs were among the first to be legislated for [29]. Member states must mandatorily recognise POs if they meet sector-specific recognition criteria for the following sectors: fruit and vegetables, olive oil and table olives, silkworm, hops, milk and milk products' [25]. There is a lack of EU-level data on the number of POs operating EU-wide and following a study of IBOs [30] a study has been recently commissioned by the EU to profile POs and to present an 'analysis of the best ways for producer organisations (POs) to be formed, carry out their activities and be supported' [31].

POs, according to a requirement of Article 152 of the CMO regulation, must be established on the initiative of producers and controlled by them. In addition, POs should undertake at least one of the following activities (Table 1):

Table 1. Activities of Producer Organisations.
(i) joint processing;
(ii) joint distribution, including by joint selling platforms or joint transportation;
(iii) joint packaging, labelling or promotion; (iv) joint organising of quality control;
(iv) joint use of equipment or storage facilities;
(v) joint management of waste directly related to the production; (vii) joint procurement of inputs;
(vi) any other joint service activities pursuing one of the objectives listed in point (c) of this paragraph *

EU CMO Regulation 1308/2013, Article 152 (29 December 2017). * Paragraph (c) of EU CMO Regulation 1308/2013, Article 152 (29 December 2017).

Benefits arising from POs for producers are identified in the literature, including the strengthening of farmers' bargaining power upstream and downstream; decreasing risk; facilitating access to new 
markets; higher incomes; improved social cohesion, partnership and trust, among others ([29], pp. 4-5). Policy benefits for farmers arising from the establishment of POs include research and development supports specific to sector (European Commission, 2018); funding supports through the EAFRD (e.g., Article 27 of EU Rural Development Regulation (1305/2013); certain exemptions from competition rules; and, specifically, the creation of favourable rules where products differentiated according to PGI (see Articles 150 \& 172 of CMO Regulation 1308/2013) [25]).

\subsection{Associations of POs and Interbranch Organisations}

EU regulations that govern the operation of POs also provide for the establishment of Associations of POs (APOs), which are formal collaborative associations of multiple POs horizontally. Furthermore, vertical collaborations between different actors in the supply chain, take the form of Interbranch Organisations (IBOs) (Article 157 of EU Regulation 1308/2013). Articles 32 and 33 of Regulation 2017/892 regulate Transnational POs and Transnational Associations of POs, supporting cooperation across international boundaries. All such national and international collaborations between individual POs are especially critical for their success, mainly because of the difficulties experienced otherwise in achieving scale and sufficient representativeness of farmers (and volume of product) in the marketplace [25]. However, while individual, independent POs cooperating via federated-type structures may maintain aspects of their flexibility and autonomy [32], it is important to note that while the economic performance of a PO may be positively correlated with its size, 'larger POs could also be associated with structural complexity and reduced flexibility' [29].

In this context, IBOs are 'vertically integrated organisations which comprise producers and at least one member of the processing or trading part of the supply chain,' with the primary aim of providing 'a means of allowing dialogue between actors in the supply chain and in promoting best practices and market transparency' [11]. IBOs are particularly crucial for the success of POs and currently, there are 128 IBOs operating in the agriculture sector EU-wide. Ten of these are categorised as beef and veal POs [25]. For example, the Provacuno IBO represents $85 \%$ of Spain's beef industry $(542,000$ tonnes annually, comparable to Ireland's annual beef production) and produces, processes and markets Beef from Spain. The Provacuno IBO has a membership of five regionally organised beef farmer-owned POs, each with their individual brand and six processors and trading partners [33]. Coordinating collaboration between POs and between POs and processors, the IBO undertakes functions such as 'defending the interests of the beef industry from production, throughout processing to trading' and 'preserving the functional efficiency of the beef value chain' [33].

While there are numerous examples of POs, APOs and IBOs operating in various sectors across Europe, it is also the case that concerns are cited in the literature. Previous research shows that the promotion of co-operation through POs tends to over-focus on supply related issues without due consideration for demand related problems ([16], p. 51). Where POs are limited in size and alternatives buyers for members' produce exist, POs are vulnerable to pressure placed on them by buyers [16]. POs vary in form depending on the institutional context and product, which results in diverse activities, economic dimensions, legal status and internal structures ([34], p. 259). Critically, however, POs should be set up on the initiative of producers and should aim to increase the economic performance of members by tailoring production and sales to market demand [13,35]. Policy promotion of POs highlights the benefits gained by farmers as a result of working together to improve efficiency and consolidate supply [16]. Ownership and decision-making are, however, at the discretion of the membership. Typically, POs are organised as agricultural co-operatives and the co-operative model represents one of the main legal entities recognised as suitable for a PO under the EU PO Regulations. Co-operatives are flexible, adaptable business models $[36,37]$ and are user-owned, user-controlled and user-benefit organisations, making them appealing structures for the establishment of POs [35,38]. Internationally, the literature indicates that the existence of social capital, particularly trust between producers as a result of informal co-operation, is a significant factor in positively influencing the decision to join or establish a PO $[25,35]$. 
Where IBOs are concerned, interviews with key informants in Ireland indicated difficulties experienced by IBO members, particularly primary producers [39]. Retailers can dominate how IBOs operate, particularly in relation to stipulating to producers' production processes as well as product standards and characteristics [27]. Key informants in Ireland had the view that IBOs are facilitating an ongoing shift in monitoring responsibilities of production and product standards away from statutory agencies to private retail conglomerates driven by corporate mandates [39]. POs have been heretofore specific to the horticulture sector in Ireland, with a tomatoes/cucumber/peppers PO and a mushroom PO operating in 2018 (a strawberry PO has recently ceased operating). According to interviews conducted by POs could experience difficulties in competing with vastly larger POs/companies operating in other European and non-European countries; difficulties in operating in accordance with EU schemes; and internal cooperation-related difficulties [39]. Key informants highlighted the need for an effective regulatory framework that governs the production standards and operation of members. Insufficiently regulative modus operandi was identified as representing serious threats to the operation of POs. 'Trust' between members was insufficient for regulating POs, in their views ([39], p. 11). A characteristic of Irish horticultural growers in particular is that they can wish to retain their direct association with their product in relationships with retailers/purchasers [27,39]. For producers with established marketing arrangements with retailers/purchasers, joining a PO entailed the replacement of such arrangements with contracts between the $\mathrm{PO}$ and the retailer/purchaser, thus breaking the pre-existing direct link [39]. The experiences of Irish fruit and vegetable POs provide cautionary lessons in relation to the need for POs to be flexible in maintaining linkages between producers and products in a marketplace where proximity between producers and consumers is increasingly sought after [40,41].

Revealing the intricacies of coordinated beef production and marketing, previous research presents a study of US beef co-operative and the nature of contractual arrangements between the co-operative, processors and retailers [42,43]. The authors found that a beef cooperative's integration to a values-based supply chain (VBSC) involving contractual arrangements vertically between across-chain actors (e.g., the co-operative, processors and retailers) led to enhanced trust, transparency and profits for all chain partners. VBSCs are characterised by commitments and contractual arrangements between chain actors, supporting fair distribution of profits and business agreements of appropriate extended duration [44,45]. Furthermore, VBSCs produce differentiated, premium products which embody social, cultural and economic values and, typically, credence attributes such as organic, high animal welfare or hormone-free.) By co-ordinating elements such as forecasting production volumes 18 months in advance and setting prices to reflect costs accumulated across the chain (e.g., those at farm-level, processing level and distribution level) has allowed for appropriate sustainable pricing planning, which incorporates a profit margin for all chain partners. The VBSC that takes the study's focus is similar in structure to an IBO.

\subsection{Adding Value}

There is a direct association between POs and the pursuit of high valued-added markets. PO legislation provides specifically for products differentiated according to PGI, for instance (Articles 150 \& 172 of EC Regulation 1308/2013; European Commission, 2018). Authors argue that POs tend to be more successful when they pursue higher value-added markets rather than undifferentiated commodity markets [46,47]. Authors [48] suggest that to pursue higher value-added markets, producers need to focus on quality-enhancing attributes that are difficult to replicate [49]. By enhancing product quality, not only are producers enabled to command premium prices but also they can compete on quality and not solely on the price 'race-to-the-bottom' generally associated with the commodity markets. Because most agricultural commodity prices are dictated by global supply and demand, it is crucial that POs have the ability to innovate and add value to ensure the long-term viability and sustainability of farmers ([50], p. 17). 
The distinction between value and volume of produce is a recurring theme in agricultural development debates. At farm-level, arguments that increases in scale are positively associated with improvements in farm viability are tenuous at best. A recent Irish study of the beef sector found that there are few, if any, economic returns from increasing the scale of beef farms [51]. On the other hand, increasing attention is paid to the economic potential arising from adding value to produce rather than increasing its volume [41]. Quality attributes are increasingly sought after by consumers and in this context policy-oriented documents promote the production of food "that is demonstrably superior from multiple (quality, safety, health and environment) perspectives" ([52], p. 39, [53,54]). Ireland's policy Food Wise2025 explicitly emphasises the need to build on increasing value over volume and targeting higher value-added markets as a means of increasing economic returns at farm level ([55], p. 35).

Marketing differentiated farm produce through Short Food Supply Chains (SFSCs) (characterised by enhanced proximity between consumers and producers) is identified by EU policy an area of development opportunity because of 'high consumer expectations (e.g., traceability, food safety/health, animal welfare, environment protection) coupled with high EU standards offers opportunities for high-value markets' ([27], p. 8). Approximately $15 \%$ of EU farms sell more than half of their produce directly to consumers and most of these are smaller farms (between 1 and 8 Economic Size Units, ESUs) ([27], p. 8). Integration of farms to SFSCs varies across the EU, ranging from an estimated $4 \%$ in Ireland [56] and less than 5\% in Malta, Austria and Spain to 21\% in France and 25\% in Greece ([27], p. 8). Half of French farmers producing vegetables and honey are integrated to SFSCs, selling directly to consumers [27].

Acquisition of officially recognised unique status for food products is an approach used EU-wide to add value. The EC officially recognises products with proven protected designation of origin (PDO), protected geographical indication (PGI) and traditional specialities guaranteed (TSG). While in Ireland, there are just seven registered PGI/PDO products, one of which is a fresh meat (lamb) product, there are currently 163 registered PDO/PGI/TSG products under the category of 'fresh meat and offal' Europe-wide (11\% of all designated products registered) [57]. In Spain, for instance, almost $6 \%$ of beef marketed through the Provacuno IBO has PGI designation and 3\% is marketed as organic [33]. An effort was made in the past to have grass-fed Irish beef recognised as having unique designation, which was unsuccessful. However, that is not to say that designation of more specific Irish beef products is not possible and the establishment of co-operatives to market PGI meat products is an area of potential identified [7], though previous research describes the support of groups aiming to pursue PGI designation in Ireland as largely unfavourable [58]. Differentiating Irish produce, particularly meat (one of Ireland's largest agricultural sectors), represents untapped potential in an evolving market where quality attributes are increasingly sought after by consumers [27,41,59].

That Ireland is 'green' and 'small not multinational' is a valuable market differentiator according to marketing experts but some Irish industry actors can be unaware of the strategic value of this differentiator ([53] personal communication). Notwithstanding this, Quality Assurance (QA) accreditation has formed an instrumental strategy in promoting Irish beef produce worldwide [60]. The QA scheme operated by Bord Bia verifies that beef and other products, are produced sustainably on certified farms and adhere to elements of food safety, animal welfare, traceability and environmental protection at production level [60]. The 'Sustainable Beef and Lamb Assurance Scheme' (SBLAS) counts 52,000 beef farmers as participants [61]. The Origin Green scheme is also of growing importance in the marketing of Irish Produce. The Origin Green sustainability report for 2016 ([62], p. 14) confirms that since 2011, 117,000 carbon assessments have taken place on over 49,000 participating Irish beef farms. Nearly all beef produced in Ireland (95\%) is accredited through the scheme as well as $85 \%$ of all dairy products [62]. Representing the 15,000 Irish dairy farmers participating in the Origin Green initiative are some private, typically small scale, dairy processing companies; and several large farmer-owned cooperatives such as Glanbia, Lakeland Dairies, Aurivo and Carbery. By contrast, Origin Green represents just one beef farmer who sells directly to the market. The remaining members selling beef are large privately owned processors, with no beef farmer-owned co-operative or representative 
organisation [63]. Furthermore, in a review of Origin Green, the authors observe, 'Much of the marketing of Origin Green relates to biodiversity and the image of high nature value (HNV) farmers in places like the Burren and in our many upland areas yet the Origin Green itself does nothing to provide additional financial support to these exemplar farmers' ([64], p. 9). It was found that while sustainability gains have been achieved by the initiative, 'green washing' must be avoided ([64], p. 5).

The smaller and more extensive farms have been recently studied [65]. Adding credence to the 'clean, green image' and visual aesthetic provided in particular by extensive beef and sheep farms in the Irish countryside, a recent survey of smaller farms ( $56 \%$ of total farmland) undertaken by Teagasc's National Farm Survey (NFS) found that nitrogen and phosphorous balances on a per hectare basis are lower on smaller farms than larger farms, smaller farm systems are low-input; and on smaller farms a high proportion of grass is used in animal diets [65]. Per hectare, smaller farms emit fewer greenhouse gas emissions but this is dependent on their low level of (meat) output [65]. These attributes, together with the inter-generational heritage of Irish family farms and their close human-ecological relationships, provide highly valuable attributes for the development of a strong farmer-owned Irish beef brand $[40,66]$. That such a brand is farmer-owned is a necessary characteristic for recognition as a genuine SFSC [40]. Clearly, it is neither possible nor desirable for many small beef farmers to develop such a brand individually and collective action is recognised internationally as a solution in this context [32,40].

While there are several beef POs in the EU and many add value to at least a proportion of their produce, in the United States, there is a particularly luminary example of a beef cooperative, similar in function to a PO, that markets beef products with the same differentiating characteristics as Irish grass-fed beef currently marketed in the US. The cooperative was integrated to a VBSC, which is consistent with the structure and objectives of POs and APOs but IBOs in particular. The study of the US beef co-operative showed how integration to a VBSC with chain partners (processors and retailers) led to enhanced trust and transparency between chain partners [42]. Also, producing premium beef products and setting prices based on cost of production (to cover costs at all levels of the chain led to fairer distribution of economic returns for chain partners. The catalyst for farmers' formation of a cooperative and integration to a VBSC was increasingly poor farm-level economic viability. A small number of ranchers recognised potential to market their beef as a premium product, differentiated according to a few main attributes: a co-operative of 'local' (initially one state) ranch families; producing rancher-owned 'birth to box' 'natural' beef, that is, pasture raised without ingestion of antibiotics, hormones or artificial ingredients. The farmers increased their viability significantly and today the cooperative, originally established in 1986, has a membership of 60 ranchers [42].

\section{Materials and Methods}

Permission from DAFM was sought and subsequently granted to the authors to access all submissions made to DAFM during its 2014 consultation process regarding the introduction of PO legislation. The methodology used in this study relied on content analysis of all fourteen submissions made to the DAFM by Irish beef industry stakeholders (see Table 2); and additional expert interviews (14) conducted with key informants in the Irish beef sector in 2016 (see Table 2). Representatives of current beef producer groups (7) and representatives of meat processors (3) were interviewed. Other interviewees (4) were selected based on their associations with agricultural policy and legislation development; the meat-processing sector; the co-operative sector; and food marketing. It is important to note that producer groups, which may be registered as private companies or cooperatives, are different to POs because they are not recognised by dedicated legislation. 
Table 2. Stakeholder submissions and interviews.

\begin{tabular}{cc}
\hline Stakeholder Submissions (14) & Stakeholder Interviews (14) \\
\hline Farmer representative groups (5) & DAFM (1) \\
\hline Current producer groups_-various sectors (3) & Representatives of current beef groups) (7) \\
\hline Extensions agents (1) & Representatives of meat processors (3) \\
\hline Sector associations and representatives (4) & Co-operative body (1) \\
\hline Statutory body (1) & National Food Board (1) \\
\hline
\end{tabular}

Source: Authors' data.

A semi-structured interview approach was adopted, using open-ended questions to ascertain participants' views in relation to the potential of beef POs, their structure, governance, role and remit. All interviews were recorded and transcribed. The transcripts together with the written submissions to DAFM were analysed thematically. Thematic analysis utilises a systematic approach involving identifying and coding key themes arising in the data $[67,68]$. Themes that arose during analysis largely corresponded to the questions asked during the DAFM PO consultation process (see Table 3).

Table 3. DAFM's Consultation Questions.

1. What should be the minimum number of members in a PO? Should there also be an upper limit fixed on the number of members involved?

2. What are your views on the structure and governance of producer organisations? This includes commercial entities versus non-commercial groups, leadership structures, boards of directors, governance etc.

3. What do you see as the main role of producer organisations (see Article 152)? Should they have a particular focus on for example, Research and Development at farm level, initiatives in the field of marketing and promotion, focus on on-farm efficiencies, progress sustainable farming techniques, climate change mitigation and other aims set down in Regulation 1308/2013 Article 152?

4. Do you see a role for POs becoming involved in contractual negotiations between producers and processors?

Source: DAFM (2014).

There are some limitations to this research. The research is limited to an analysis of stakeholders' submissions to DAFM and 14 interviews. Conducting a survey of Irish beef farmers to gain insights to their awareness of and views about beef POs was beyond the resources of this research project. However, while the number of submissions submitted to DAFM's consultation is low and represents a self-selecting cohort, the number and content of the submissions is also indicative of the breadth and nature of Irish stakeholders' current interests in POs. The selection of interviewees was conducted purposively as a method of verifying the information contained in the submissions, gauging the representativeness of the views presented therein. There was overall consistency between the views presented in the submissions and the views elicited in the interviews, with no significant divergences.

\section{Findings}

\subsection{Size of Producer Organisations: Membership, Volume of Production and Market Share}

This section presents the analysis of findings from the submissions and interviews. The findings are presented under the headings used to structure the DAFM submissions including the size of POs; 
their structure and governance; their role and more specifically their role in contractual negotiations (Table 3).

There were varying views among stakeholders in relation to the number of members a PO ought to have. While two submissions suggested there should be no minimum membership, others suggested specific minimum membership numbers (ranging from as low as 2 to as high as 50 members and others suggested there should be no upper limit on membership as long as the organisation remained representative and in the control of members. Other stakeholders suggested that thresholds of output would be a more appropriate approach to determine size than numbers of members. One submission, for example, proposed that it should be based on "tonnage or volume produced rather than the number of members." A representative of an existing beef producer group highlighted that market share was a more substantive way of determining the appropriate threshold for membership and output of a beef PO stating:

"If [a] group want to set up they need to have at least $25 \%$ of the market share in order to kick start it ... in order to have some clout."

However, one submission highlighted that, considering only $10 \%$ of Irish beef is consumed domestically, one PO could potentially satisfy total domestic consumption and still account for less than $15 \%$ of national production. Additionally, there were no references in the submissions to production thresholds of APOs or IBOs, possibly indicating a lack of awareness.

\subsection{Structure and Governance}

Most of the submissions stated that POs should function as commercial entities while other submissions believed that "It should be agreed by the farmers involved." The co-operative model was acknowledged as the most suitable organisational structure for PO's by both submissions (7) and interviewees The co-operative is recognised as a familiar and readily adaptable component of the institutional framework of Irish agriculture, with one interviewee presenting it as "the best and most appropriate form that would provide the leadership structures, board of directors, governance and democratic accountability to PO members".

One producer group representative interviewed had the view that, if farmers had a say all the time, it could make negotiations with their partnering processors laborious. It was also suggested in one submission that professionals in marketing, distribution and co-ordination should be contracted by POs if needed but "a non-executive farmer/producer/manager could provide day to day running of the group under the authority of the committee with secretarial assistance".

The issue of the geographic representativeness of POs was also questioned, with one submission noting that:

"Certain geographic parameters should be set for POs to avoid disparate combination of PO members (spread across the country) which would make effective operation and cohesion of the group more difficult."

The need for a clearly defined set of rules emerged strongly from the findings as being pivotal to ensure group commitment, trust, cohesion and loyalty:

"Clarity needed on whether or not members of a PO can negotiate individual deals while also at the same time being a member of a PO which is involved in negotiations on behalf of a group of suppliers, regarding a defined supply of cattle ... there should also be rules in relation to the minimum period of membership to ensure that the structural validity of the PO is not compromised."

One existing beef producer group representative pointed out that processors represent one potential barrier to $\mathrm{PO}$ development, yet farmers also could potentially undermine the model through lack of commitment: 
"You know either the meat factories will break it up, or they (farmers) will break it up themselves by not really adhering to it."

There is a view that, even if processors do engage, POs could be destabilised by processors offering some members premiums:

"It's going to be very easy to undermine a beef producer group because of a factory deciding ... to offer one or two of the group an extra 10 cents a kilo and that's all it will take... holding the group together is going to be very difficult ... especially because it's in a start-up phase."

There are also views that while the aim of POs is to bring smaller producers together to create economies of scale and enhance bargaining power, there is a chance that bigger producers may in fact benefit more. Such unintended consequences have transpired in other sectors, for example, in the Irish mushroom industry, where the number of smaller suppliers (producing non-differentiated commodity products) declined while the larger suppliers continued to grow due to their ability to increase in scale and to maintain and meet buyers growing demands. This led to consolidation within the mushroom industry.

Existing Vehicles for PO Development

There was recognition in the submissions and interviews that pre-existing networks, most particularly discussion groups (including those supported/established under the Beef Technology Adoption Programme (BTAP). The BTAP funds beef farmers to come together for group discussion in areas such as financial management, grassland management, herd health, animal breeding/welfare and producing animals to market specifications. The scheme has now been replaced by Knowledge Transfer (KT) Groups, which could provide a forum for establishing POs:

"POs offer the potential for horizontal co-operation between farmer members of POs and also vertical co-operation between POs, marts and processors. The horizontal co-operation could potentially be harnessed through the existing BTAP discussion group infrastructure as a preliminary conduit."

Currently, POs can avail of up to $€ 3000$ worth of advisory services from the Rural Development Programme (RDP) to aid their development [69]. However, policy-driven and funding-led incentives were observed as having potentially negative implications. One producer group representative, for example, observed that financial incentives offered to farmers to become involved in discussion groups led to opportunistic behaviour and negatively impacted the dynamic of pre-existing discussion groups:

"We had working discussion groups already and then a scheme came out to try and encourage people and you got a very, very diverse range of people joining those discussion groups from people with loads of ability to people with no ability all in the one group. The same thing ... could potentially happen with these POs ... everybody will sign up to them ... what criteria do you set for joining them, how do you manage it, what are the requirements for being in it ... producer groups that came about organically, came about because a desire already existed."

The issue of beef POs potentially undermining the only co-operative structure, the mart structure, in the Irish beef sector also arose. Currently, the livestock marts provide an arena for selling cattle and ensuring payment. One stakeholder noted, "at the present time the amount of finished cattle being sold through marts has declined and could further decline if POs become established." However, some submissions and interviews alluded to the potential of livestock marts and beef POs to operate collaboratively. It was suggested that livestock marts could, in fact, diversify to function as POs and could potentially organise into an IBO nationwide:

"One group of 30 farmers ... will not hold sway and will not have the clout to create a group for themselves ... they will have to be linked with [other groups]. It will have to be co-ordinated as one joint effort nationally." 


\subsection{Roles of Producer Organisations}

More than half (8) of all submissions stated that the main function of PO's should be negotiating with processors on price. This perspective also emerged from interviewee narratives, with one stating:

"You can now negotiate on price whereas before you couldn't ... they [can] come together, try and hammer out a price because it's now legal. If they tried to do that before the legislation, they could all be in court."

Other submissions noted that there is scope for POs to undertake other roles identified in the EU regulation. One submission outlined that POs should not be "set up solely to focus on selling output". Other aspects that emerged as fundamental included all year-round supply; on-farm efficiency; and adhering to and responding to market demands. Submissions (3) noted that there are already " $a$ number of organisations such as Teagasc, Bord Bia etc. that have expertise and programs in [these] areas".

Just two submissions identified the potential of POs in adding value to beef produce by using:

"Our world advantage of grass-based beef production and image ... the national herd ... currently consists of over 1 million suckler cows and their progeny constitutes the bulk of our marketable image of grass-fed Origin Green beef."

The National Food Board representative concurred with this point noting that:

"If you are a very strong farmer owned PO but are not ... offering what the consumer wants ... if it's not giving a significant advantage over what's out there ... it's not going to be successful."

Many of the current beef producer groups operate with some element of value added to their product, that is, breed based or organic. However, one beef producer group stated they their group had previously considered pursuing the added value route did not because it "involves a whole other layer of management. I mean there is a sales element to that and other expertise that we don't have". It was also noted by one producer group representative that in pursuing the premium markets there is a constant need to remain progressive in line with consumer demands:

"What we were providing within a few years became standard for the industry and now we need to look for the next differentiation."

Therefore, POs taking a value-added approach need to be cognisant of not only changing consumer demands in value-added market segments and being more innovative but also focused on the challenges of maintaining premiumised differentiation from the output of commodity beef chains, where standards are continually being raised.

\subsection{POs and Contractual Negotiations}

While beef POs have multiple possible functions, the role most commonly identified by stakeholders related to the collective establishment of sales contracts between farmers and processors. By utilising sales contracting, both processors and farmers could reap the security and advantages of co-ordinating cattle supply that would meet market specifications at "the right ... times of the year when they would be most in demand". For processors to engage in sales contract negotiations with POs, it was stated by processors that they would need to see the ability of the PO to respond to market and industry demands, as well as consumer demands by supplying:

"A critical mass, a minimum number of people in a producer group and, as importantly, a minimum number of cattle and you'd need to see when they are going to come through. Because obviously seasonality plays a role, so you don't want to ... see them all coming in September for example. So, there would be quite a bit of work to be done to get the right mix within a group to match the market requirements." 
Just one submission stated that POs should partner with all chain 'agents' and have the power to "strengthen the 'power' of farmers (producers) in the supply chain relative to economic agents upstream and downstream from the farm gate". IBOs, as well as POs, have been legislated for in Ireland and it is clear from myriad existing initiatives such as Origin Green that collaborative schemes and partnerships are already functioning in Irish and international markets between actors who choose to work together.

The submissions and interviews suggest that one of the biggest challenges for prospective POs is entering into agreements with processors. More than half of interviewees (8) held the pessimistic view that for as long as processors can access cattle supplies outside of POs, there will be little incentive to enter into negotiations for sales contracts. While one of the processors interviewed already works with producer groups, other processors were questioned on their openness to working with these new beef POs, with one stating

"We probably would be open to them but like ... through the years we'd have a good relationship built up with farmers that are continuously supplying us ... so we wouldn't really see the need for a producer group because ... in our opinion from what we would have seen in the past ... is that all it would have led to is an extra cost really."

Another processor stated that they could not commit to partnering with POs and entering into sales contracts as the market was constantly changing. While processors may not have seen the need to engage with such POs in the immediate term, however, many were not dismissing engagement as a future option. The market situation and cattle supply issues appear to be the main factors determining processor engagement.

The use of contracts was perceived as pivotal to the success of prospective beef POs but developing such contracts would require more market price transparency. While prices paid to producers are reported by the DAFM and retailer prices are reported, there is "no reporting of wholesale prices in the trade". In the US, for example, beef trade prices are reported at the farmer, wholesale and retail level on a daily basis, which facilitates transparency and enables informed contracting.

\section{Discussion and Conclusions}

While PO legislation for Ireland's beef sector is new, that is not to say that the country's livestock sector and the emergence of collective action in particular has not been analysed in the literature longitudinally [22,70-73]. While a separate paper is required to assess lessons of the past for navigating current challenges, we are aware that much of what we report about the contemporary scene would, from a historical perspective, represent a case of 'plus ça change, ne change rien'. While this is so, it is timely to reflect on whether features of agricultural cooperation of the 21st century offer a resilience strategy in what commentators describe as seriously threatening times for suckler farmers [74].

Legislation of the EU regulation in Ireland not only offers opportunities for the establishment of farmer-driven collective organisations of Irish beef farmers but for these organisations to collaborate with other segments of the chain, for example, processing and retailing. The ultimate goal of such endeavours would be for farmers to become 'part owners' of the supply chain and enhance their viability $[75,76]$. Existing supply chain relations, however, pose significant challenges for the development and growth of new beef POs. Challenges have been identified in media discussions of prospective beef POs in Ireland, citing challenges experienced by horticultural POs in the past. In the farming media, it has been reported that 'POs could have the same transformative effective on the beef industry as the coops had in the dairy sector in the 1920s and 1930' but 'there will be resistance to a change in the status quo' [77].

According to international evidence, $\mathrm{PO}$ legislation offers many potential functions and benefits to Irish beef farmers, including collective bargaining, joint promotion, co-ordinating and joint purchasing of inputs including equipment and storage and the joint management of waste directly related to the production of live cattle, for example, exporting slurry. Other benefits include increased incomes, creation of bargaining power, reduced risks and transaction costs due to increased scale, among 
others [29]. The tradition of the co-operative model in the dairy sector and grass roots movements including marts and discussion groups, provide a backdrop for the successful establishment of beef POs. The livestock mart system was identified in stakeholder submissions as having the potential to facilitate POs, or even Associations of POs, due to their co-operative structure and national reach. The potential roles of marts to engage and the practicalities of such arrangements require further exploration. Indeed, the horizontal and vertical forms of cooperation promoted by POs (and APOs) have been recommended measures to safeguard the viability of marts in particular for almost two decades [23]. Furthermore, discussion groups may provide a forum to stimulate the establishment of POs.

However, challenges to successful PO establishment and operation were also highlighted by interviewees and in submissions made to DAFM and interviews, specifically poor member commitment and processor engagement. In the context of Ireland's successive beef 'crises,' the main goal associated with POs is a rebalancing of power in the supply chain and to improve the bargaining power of farmers in dealing with other chain actors, particularly processors. Stakeholders indicate that this will represent a major challenge. Many believe that only increased consumer demand for beef will make processors willing to engage with POs. Other stakeholders suggested that a sufficient proportion of beef output and farmers must be represented by POs because, otherwise, processors will not need to engage with POs. Such views are consistent with international experience, which highlights the need for POs to represent a critical proportion of total produce available in the market.

A nationally co-ordinated approach is favoured by some stakeholders, which would ideally require planning from the outset of the establishment of individual POs. Such a coordinated approach is taken internationally in the form Associations of Producer Organisations (APOs) and also Interbranch Organisations (IBOs), which include collaborative arrangements with other actors in the chain such as processors. Recently proposed EU legislation to protect primary producers in particular against unfair trading practices will serve to further enhance the collaborative arrangements between chain actors [78]. Furthermore, policy support of the 'collaborative economy' is another area of EU activity that should be considered in the context of creating imaginative ways of bringing consumers into contact with primary producers [79]. Examples such as 'Crowd Cow' in the United States is one such example. The literature indicates that a coordinated approach is a successful route for the development of POs, rather than fostering the establishment of individual, smaller and potentially competing POs. A similar federated model is advocated by the US 'Agriculture of the Middle' model [32,76,80], providing benefits of a local co-operative while linked horizontally to other co-operatives for solidarity and scale. Therefore, local identities and ownership, which are important attributes in the value-added market, are retained while operating in a co-ordinated national movement. The preservation of localised regional structures while also drawing support from horizontal and vertical forms of integration is likely to be important to livestock marts in particular [23].

While adding value to products is identified in the literature as enhancing profitability of POs and member farms, there was poor awareness in submissions and among interviewees. Some beef producer group representatives cited lack of expertise in sales and marketing as a reason for not adding value to their products. However, Irish beef (sold by processors) is already promoted by schemes such as Origin Green as differentiated according to sustainability attributes and beef branded as grass-fed is already considered a premium product in the market place. Attributes of smaller-scale Irish beef farms in particular, which are largely unprofitable yet attractive to consumers from socio-cultural and environment perspectives, could be valorised by using branding and marketing strategies on the part of a collective of farms. Smaller farms, those currently operating $56 \%$ of total Irish farmland, have particularly favourable characteristics $[65,66]$.

Knowledge gaps were also evident throughout analysis. Interviewees such as representatives of current beef producer groups indicated that they knew little about the policy and many were unsure as to what it could offer them. While a nationally coordinated approach was referred to in submissions and interviews, there were no references to APOs or IBOs. IBO functions have clear application in the 
Irish context and the absence of references to IBOs in stakeholder could conceivably at least partially be explained by the consultation process text drawing attention to a certain selection of Articles of the EU Regulation 1308/2013 (152-156 \& 170, since repealed), which include Associations of Producer Organisations but make no reference to Interbranch Organisations.

Furthermore, the introduction of PO legislation has not received widespread media attention to date. This may change, however, with the implementation of two measures in 2018/2019 to support the establishment of POs, which provide advisory services to the value of $€ 3000$ to up to 100 individual groups. The advisory services will assist prospective POs to establish themselves legally and operationally, for instance in coordinating beef production. While the focus is currently on establishing individual POs, the longer-term vision for the establishment of APOs and IBOs must be maintained. A crucial lesson from international experience is that POs operating alone may languish. Furthermore, the establishment of individual POs may appear all the more attractive to beef farmers where supports and favourable contractual arrangements are from APOs and IBOs are available. Otherwise, if supports such as those provided by APOs and IBOs are likely to be unavailable, farmers may justifiably judge with scepticism the future sustainability of POs.

Author Contributions: M.-W.Á., H.T., M.O. and P.C. designed the research; H.T. conducted and analysed the research with contributions from M.-W.Á. and support from M.O., P.C. and H.M., H.T. and M.-W.Á. wrote the paper with contributions from M.O., P.C. and H.M.

Funding: This research was funded by [Teagasc Walsh Fellowship Scheme] grant number [00215].

Acknowledgments: The authors would like to acknowledge by the Walsh Fellowship Scheme, Teagasc (the Irish Agriculture and Food Development Authority) for funding this research.

Conflicts of Interest: The authors declare no conflict of interest.

\section{References}

1. Bord Bia. Factsheet on the Irish Agriculture and Food and Drink Sector; Bord Bia: Dublin, Ireland, 2018. Available online: https://www.bordbia.ie/industry/buyers/industryinfo/agri/pages/default.aspx (accessed on 12 June 2018).

2. Burke, T.; Roche, M. Teagasc National Farm Survey 1999; Teagasc: Sandymount, Ireland, 1999.

3. Connolly, L.; Kinsella, A.; Quinlan, G. Teagasc National Farm Survey 2003; Teagasc: Sandymount, Ireland, 2003.

4. Hennessy, T.; Moran, B. The Viability of the Irish Farming Sector in 2015; Teagasc: Athenry, Ireland, 2015.

5. Dillon, E.; Moran, B.; Donnellan, T. Teagasc National Farm Survey 2016; Teagasc: Athenry, Ireland, 2017.

6. Murtagh, A.; Ward, M. Structure and Culture: The Evolution of Irish Agricultural Cooperation. J. Rural Coop. 2011, 39, 151-165.

7. Irish Co-Operative Organisation Society (ICOS). Dublin. 2018. Available online: http://icos.ie/ (accessed on 10 April 2018).

8. Frawley, J.P.; Commins, P. The Changing Structure of Irish Farming: Trends and Prospects; Teagasc: Sandymount, Ireland, 1996.

9. Renwick, A. From blockades to supply chain integration: Challenges of Co-ordination in the Agri-food sector. In A Presentation to Teagasc; Teagasc: Athenry, Ireland, 2015.

10. Cadogan, S. 'Beef producer Organisations Will Deal Direct with Processors'. Irish Examiner Newspaper, 7 January 2016. Available online: http:/ / www.irishexaminer.com/farming/news/beef-farmer-producer-or ganisations-will-deal-direct-with-processors-374751.html (accessed on 1 December 2017).

11. European Commission. 2017. Available online: https://ec.europa.eu/commission/index_en (accessed on 27 November 2017).

12. Penrose-Buckley, C. Producer Organisations: A Guide to Developing Collective Rural Enterprises, 1st ed.; Oxfam: Oxford, UK, 2007; 186p.

13. Falowski, J.; Cianin, P. Factors Supporting the Development of Producer Organizations and Their Impacts in the Light of Ongoing Changes in Food Supply Chains. 2016. Available online: http://publications.j rc.ec.europa.eu/repository/bitstream/JRC101617/jrc101617_jrc\%20report\%20_po_litrev.pdf (accessed on 3 March 2017). 
14. European Commission. Modernising and Simplyfing the CAP: Economic Challenges Facing EU Agriculture. 2017. Available online: https:/ / ec.europa.eu/agriculture/sites/agriculture/files/consultations/cap-mod ernising/eco_background_final_en.pdf (accessed on 10 April 2018).

15. Department of Agriculture Food and the Marine (DAFM). The Dowling Report. 2014. Available online: https:/ / www.agriculture.gov.ie/media/migration/farmingsectors/beef/beefroundtable/MichaelDowli ngReport030614.pdf (accessed on 6 March 2017).

16. Hennessy, A. 'IFA and ICSA Fear Producer Groups Concept Offside with Beef Farmers'. Irish Farmers Journal Newspaper, 4 February 2016. Available online: http:/ / www.farmersjournal.ie/icsa-calls-teagasc-statistics-on -suckler-farm-viability-disgraceful-223287 (accessed on 5 March 2017).

17. Eastham, J. Producer organisations-The way forward? J. Co-Oper. Stud. 2014, 47, 50-54.

18. Hocquette, J.; Chatellier, V. Prospects for the European beef sector over the next 30 years. Anim. Front. 2011, 1, 20-28. [CrossRef]

19. Finneran, E.; Crosson, P. Effects of scale, intensity and farm structure on the income efficiency of Irish beef farms. Int. J. Agric. Manag. 2013, 2, 226-237. [CrossRef]

20. Department of Agriculture Food and the Marine (DAFM). Local Roots Global Reach. Food Wise 2025, a 10-Year Vision for the Irish Agri-Food Industry. 2015. Available online: https:/ / www.agriculture.gov.ie/media/migration / foodindustrydevelopmenttrademarkets/agri-foodandtheeconomy/foodwise2025/report/FoodWise2025.pdf (accessed on 4 January 2017).

21. O'Sullivan, R. 'Competition Authority Is Criticised for Silence'. Irish Times Newspaper, 19 January 2000. Available online: http:/ / www.irishtimes.com/news/competition-authority-is-criticised-for-silence-1.23 5430 (accessed on 19 July 2017).

22. Shannan, E. 'Report Finds No Evidence of Beef Sector Cartel'. Irish Times Newspaper, 22 September 2000. Available online: http:/ / www.irishtimes.com/business/report-finds-no-evidence-of-beef-sector-cartel-1 .1123877 (accessed on 19 July 2017).

23. Curtin, C.; Varley, T. Collusion practices in a West of Ireland livestock mart. Ethnology 1982, 21, 349-357. [CrossRef]

24. Hennebry, E.; Pitts, E.; Harte, L. The Strategic Development of Irish Livestock Marts. 2002. Available online: https:/ / t-stor.teagasc.ie/bitstream/handle/11019/1235/eopr-4921.pdf;jsessionid=74C 2BD4CBEBB1D37F265E43194495706? sequence=1 (accessed on 10 April 2018).

25. Meikle, S. Meat Factories-A Part of the Problem or an Excuse. 2018. Available online: www.thatsfarming.com (accessed on 13 February 2018).

26. European Commission. 2018. Available online: https:/ / ec.europa.eu/agriculture/producer-interbranch-or ganisations/producer-organisations-association_en (accessed on 11 May 2018).

27. Copa Cogeca. Agri-Co-Operatives in the EU: Essence, Governance and Keys to Success. 2015. Available online: https:/ / ec.europa.eu/agriculture/sites/agriculture/files/agri-markets-task-force/con tributions/concrete/copacogecaagricooperatives_en_.pdf (accessed on 14 April 2017).

28. Department of Agriculture Food and the Marine (DAFM). National Strategy for Sustainable Operational Programmes 2017-2022. 2018. Available online: https://www.agriculture.gov.ie/media/migration/farming sectors/horticulturebeekeeping/horticultureschemes/NationalStrategySustainableOPsOct2017Dec20220 50218.pdf (accessed on 2 May 2018).

29. Van Herck, K. Assessing Efficiencies Generated by Agricultural Producer Organisations. 2014. Available online: http:/ / ec.europa.eu/competition/publications/agricultural_producers_organisations_e n.pdf (accessed on 5 February 2017).

30. Arcadia International. Study on Agricultural Interbranch Organisations in the EU. 2016. Available online: https:/ / ec.europa.eu/agriculture/sites/agriculture/files/external-studies/2016-inter branch-organisations/fullrep.pdf (accessed on 24 March 2018).

31. Arcadia International. Analysis of the Best Ways for Producer Organisations (POs) to Be Formed, Carry Out Their Activities and Be Supported; European Commission: Brussels, Belgium, unpublished.

32. Lyson, T.A.; Stevenson, G.W.; Welsh, R. (Eds.) Food and the Mid-Level Farm: Renewing an Agriculture of the Middle; MIT Press: Cambridge, UK, 2008.

33. Provacuno. 2018. Available online: http://www.provacuno.es/vacuno/press-documents/thematic-sheet s_330_272_496_0_1_in.html (accessed on 10 April 2018). 
34. Bijman, J. The role of producer organisations in quality-oriented agro-food chains; an economic organisation perspective. In Governance Regimes for Quality Management; Wageningen Academic Publishers: Wageningen, The Netherlands, 2007; pp. 257-278.

35. Chlebicka, A. Producer Organizisations in Agriculture-Barriers and Incentives of Establishment on the Polish Case. Procedia Econ. Financ. 2015, 23, 976-981. [CrossRef]

36. Birchall, J.; Ketilson, L.H. Resilience of the Cooperative Business Model in Times of Crisis; Sustainable Enterprise Programme/Responses to the Global Economic Crisis, Geneva; International Labour Organisation: Geneva, Switzerland, 2009.

37. McCarthy, O.; Briscoe, R.; Ward, M. People in Control: The Promise of the Co-operative Business Approach. In Irish Business and Society; Hogan, J., Donnelly, P.F., O’Rourke, B.K., Eds.; Gill and MacMillan: Dublin, Ireland, 2010; pp. 319-333.

38. Bijman, J.; Iliopoulos, C.; Poppe, K.J.; Gijselinckx, C.; Hagedorn, K.; Hanisch, M.; Hendrikse, G.W.J.; Kühl, R.; Ollila, P.; Pyykkönen, P.; et al. Support for Farmers' Cooperatives. 2012. Available online: https:/ / ec.europa.eu/a griculture/sites/agriculture/files/external-studies/2012/support-farmers-coop/fulltext_en.pdf (accessed on 25 October 2018).

39. Macken-Walsh, Á.; Brosnan, K. The Potential of an Enhanced Cooperation Measure in the EAFRD (2014-2020): The Case of Ireland. 2012. Available online: https://www.teagasc.ie/media/website/p ublications/2012/ThePotentialofanEnhancedCooperationMeasureintheEAFRD2014-2020.pdf (accessed on 10 February 2018).

40. Macken-Walsh, A.; Hegyi, A.; Sebok, A. Protocol for the Multi-Actor Approach: AgriDemo-F2F Project (Horizon 2020); European Union: Brussels, Belgium, 2017.

41. Regan, Á.; Henchion, M.; McIntyre, B. Ethical, moral and social dimensions in farm production practices: A segmentation study to assess Irish consumers' perceptions of meat quality. Ir. J. Agric. Food Res. 2018, 57, 9-14. [CrossRef]

42. Hooks, T.; Macken-Walsh, Á.; McCarthy, O.; Power, C. The Impact of a Values-Based Supply Chain (VBSC) on Farm-Level Viability, Sustainability and Resilience: Case Study Evidence. Sustainability 2017, 9, 267. [CrossRef]

43. Hooks, T.; McCarthy, O.; Power, C.; Macken-Walsh, Á. A Co-operative Business Approach in a Values-Based Supply Chain: A Case Study of a Beef Co-operative. J. Co-Oper. Organ. Manag. 2017, 5, 65-72. [CrossRef]

44. Stevenson, G.; Clancy, K.; King, R.; Lev, L.; Ostrom, M.; Smith, S. Midscale food value chains: An introduction. J. Agric. Food Syst. Community Dev. 2011, 1, 27-34. [CrossRef]

45. Fleury, P.; Lev, L.; Brives, H.; Chazoule, C.; Désolé, M. Developing Mid-Tier Supply Chains (France) and Values-Based Food Supply Chains (USA): A Comparison of Motivations, Achievements, Barriers and Limitations. Agriculture 2016, 6, 36. [CrossRef]

46. Berdegué, J.A. Cooperating to Compete Easier Said Than Done: Available in Producer Organisations and Value Chains. 2008. Available online: http:/ / www.learning4development.org/uploads/3/3/8/9/3389888 / cap34_0708_po_eng.pdf (accessed on 26 February 2017).

47. Hellin, J.; Lundy, M.; Meijer, M. Farmer organization, collective action and market access in Meso-America. Food Policy 2009, 34, 16-22. [CrossRef]

48. Beverland, M. Can cooperatives brand? Exploring the interplay between cooperative structure and sustained brand marketing success. Food Policy 2007, 32, 480-495. [CrossRef]

49. Young, L.M.; Hobbs, J.E. Vertical linkages in agri-food supply chains: Changing roles for producers, commodity groups, and government policy. Rev. Agric. Econ. 2002, 24, 428-441. [CrossRef]

50. Department for Environment Food and Rural Affairs (DEFRA) Conditions, Attitudes and Structures of Successful POs and Cooperatives: Potential Role in Supporting a Competitive Farming Sector in England and Wales. 2014. Available online: https:/ / ec.europa.eu/agriculture/sites/agriculture/files/agri-marketstask-force/contributions/2016-05-24/ukdefracoop_en.pdf (accessed on 4 January 2017).

51. Tsakiridis, A.; Breen, J.; Hanrahan, K.; Wallace, M.; O’Donoghue, C. Feed substitution and economies of scale in Irish beef production systems. In Proceedings of the Walsh Fellowship Seminar, Rennes, France, 27-28 October 2016; Ballsbridge, Co.: Dublin, Ireland, 2016.

52. Purvis, G.; Downey, L.; Beever, D.; Doherty, M.L.; Monahan, F.J.; Sheridan, H.; McMahon, B.J. Development of a sustainably competitive agriculture. In Agroecology and Strategies for Climate Change; Lichtfouse, E., Ed.; Springer: London, UK; New York, NY, USA, 2015; pp. 35-67. 
53. Bell, D.E.; Shelman, M. Pathways for Growth Building Ireland's Largest Indigenous Industry. 2010. Available online: http://www.bordbia.ie/industry/manufacturers/insight/publications/CorporatePu blications / Documents / Pathways\%20for\%20Growth\%20Report.pdf (accessed on 6 December 2016).

54. Monaghan, M.; Downey, L.; Purvis, G. Opportunities for Sustainably Competitive Irish Agriculture: Some Strategic Intiatives towards Getting Bigger. 2015. Available online: https:/ /www.grantthornton.ie/g lobalassets /1.-member-firms /ireland/insights / publications/agri-food-strategy-group-report--2015.pdf (accessed on 5 March 2017).

55. Department of Agriculture. Food and the Marine (DAFM) National Strategy for Sustainable Operational Programmes 2017-2022. 2018. Available online: https://www.agriculture.gov.ie/media/migration/foodind ustrydevelopmenttrademarkets/agri-foodandtheeconomy / foodwise2025/FoodWise2025Implementatio nPlan.pdf (accessed on 25 October 2018).

56. Meredith, D.; Heanue, K.; McCarthy, S. Farm Development: Attitudes to Farm Diversification. In Proceedings of the Teagasc National Rural Development Conference, Tullamore, Ireland, 16 October 2012.

57. European Commission DOOR. 2018. Available online: http:/ / ec.europa.eu/agriculture/quality/door/list.html (accessed on 17 April 2018).

58. Conneely, R.; Mahon, M. Protected geographical indications: Institutional roles in food systems governance and rural development. Geoforum 2013, 60, 14-21. [CrossRef]

59. Cotter, A. Working with Nature; The Convention Centre: Dublin, Ireland, 2015.

60. Bord Bia. Farm Level Sustainability: Measuring What Matters at Farm Level. 2018. Available online: www.origingreen.ie/farms (accessed on 14 May 2018).

61. Moran, C. 'Further Consolidation in Irish Beef Processing as Kepak Acquires Munster Processor'. Independent, 16 November 2016. Available online: http://www.independent.ie/business/farming/beef/further-c onsolidation-in-irish-beef-processing-as-kepak-acquires-munster-processor-35221401.html (accessed on 19 July 2017).

62. Bord Bia. Sustainability Report 2016. Available online: https://www.origingreen.ie/globalassets/publicatio ns / origin-green-sustainability-report-2016.pdf (accessed on 25 October 2018).

63. Origin Green. 2018. Available online: https://www.origingreen.ie/who-is-involved/origin-green-companies / (accessed on 1 November 2018).

64. An Taisce, The National Trust for Ireland. An Taisce review of Origin Green 2016. Available online: http:/ / www.antaisce.org/file/1765/download?token=smfgOpx4 (accessed on 25 October 2018).

65. Dillon, E.; Hennessy, T.; Moran, B.; Lennon, J.; Lynch, J.; Brennan, M.; Donnellan, T. Teagasc National Farm Survey: The Sustainability of Small Farming in Ireland. 2017. Available online: https://www.teagasc.ie/m edia/website/publications/2017/Small-Farms-Survey.pdf (accessed on 25 October 2018).

66. Macken-Walsh, Á. Bridging the 'Urban-Rural Divide. In Society Matters Reconnecting People and the State; Reynolds, B., Healy, S., Eds.; Social Justice Ireland: Dublin, Ireland, 2017; pp. 95-129.

67. Boyatzis, R.E. Transforming Qualitative Information: Thematic Analysis and Code Development; Sage: London, UK, 1998.

68. Marshall, C.; Rossman, G.B. Designing Qualitative Research, 3rd ed.; Sage: Thousand Oaks, CA, USA, 1999.

69. Hubert, T. 'Creed Opens Tender for Beef Producer Organisations' Advisers'. Irish Farmers Journal, 28 August 2017. Available online: https:/ / www.farmersjournal.ie/creed-opens-tender-for-beef-producer -organisations-advisors-304092 (accessed on 28 November 2017).

70. O'Donovan, J. The Economic History of Livestock in Ireland; Cork University Press: Cork, Ireland, 1940.

71. Kennedy, L. Agricultural Co-Operation and Irish Rural Society (1880-1914). Ph.D. Thesis, University of York, York, UK, 1978.

72. Jones, D.S. Land reform legislation and security of tenure in Ireland after Independence. Eire-Ireland 1997, 33, 116-143. [CrossRef]

73. Ó Fahartaigh, M. Irish Agriculture Nationalised; Institute of Public Administration: Ballsbridge, Dublin, Ireland, 2015.

74. McCarthy, J. 'Save Our Sucklers Campaign', Published Online for the Irish Farmers Journal. 18 January 2018. Available online: https:/ / www.farmersjournal.ie/save-our-sucklers-campaign-33921 (accessed on 17 April 2018). 
75. Kirschenmann, F.; Stevenson, S.; Buttel, F.; Lyson, T.; Duffy, M. Why worry about the agriculture of the middle. In Food and the Mid-Level Farm: Renewing an Agriculture of the Middle; Lyson, T.A., Stevenson, G.W., Welsh, R., Eds.; MIT Press: Cambridge, UK, 2008; pp. 3-22.

76. Hooks, T.; Macken-Walsh, Á.; McCarthy, O.; Power, C. Farm-level viability, sustainability and resilience: A focus on cooperative action and values-based supply chains. Stud. Agric. Econ. 2017, 119, 123-129. [CrossRef]

77. Young, P. 'Growing Together', Published Online for the Irish Farmers Journal. 18 October 2014. Available online: http:/ / agriaware.ie/uploads / files/week_6.pdf (accessed on 17 April 2018).

78. COM. Proposal for a Directive of the European Parliament and of the Council on Unfair Trading Practices in Business-To-Business Relationships in the Food Supply Chain, Brussels. 2018. Available online: https: / / eur-lex.europa.eu/legal-content/EN/TXT/?uri=CELEX\%3A52018PC0173 (accessed on 25 October 2018).

79. COM. A European Agenda for the Collaborative Economy. Communication from the European Commission to the European Parliament, the Council, the Economic and Social Committee, and the Committee of the Regions. Brussels. 2016. Available online: https:/ / ec.europa.eu/transparency/regdoc/rep/1/2016/EN/1-2 016-356-EN-F1-1.PDF (accessed on 25 October 2018).

80. Macken-Walsh, A. The Potential of an "Agriculture of the Middle" Model in the Context of EU Rural Development: An American Solution to an Irish Problem? Agric. Food Syst. Community Dev. 2011, 1, 177-188. [CrossRef]

(C) 2018 by the authors. Licensee MDPI, Basel, Switzerland. This article is an open access article distributed under the terms and conditions of the Creative Commons Attribution (CC BY) license (http://creativecommons.org/licenses/by/4.0/). 